\title{
PEMBERIAN SUAP OLEH ADVOKAT DITINJAU DARI UNDANG-UNDANG PEMBERANTASAN TINDAK PIDANA KORUPSI
}

\author{
Stevani Gonadi \\ Fakultas Hukum Universitas Surabaya \\ Stevani_gonadi@yahoo.com \\ DOI: https://doi.org/10.23917/laj.v4i2.8800
}

Submission

Track:

Received:

11 September 2019

Final Revision:

3 Oktober 2019

Available online:

10 Oktober 2019

Corresponding

Author:

Stevani Gonadi

Stevani_gonadi@yahoo.com

\begin{abstract}
Dalam melakukan sebuah perbuatan pidana dikenal adanya penyertaan perbuatan pidana yang dilakukan lebih dari satu orang dan perbarengan perbuatan pidana yang akan menjadi penentu stelsel pemidanaan yang akan digunakan. Perbarengan perbuatan pidana merupakan perbuatan pidana yang dilakukan lebih dari satu perbuatan dan merupakan perbuatan pidana yang berdiri sendiri. Berkaitan dengan hal tersebut, STA seorang Advokat memberikan uang kepada Hakim MA sebanyak dua kali yaitu pada tahun 2010 dan tahun 2013 dengan tujuan untuk mempengaruhi putusan yang akan diputus oleh Hakim MA terhadap perkara yang sedang diajukan oleh STA. STA merupakan pelaku tindak pidana korupsi berdasarkan Pasal 6 Ayat (1) huruf a Undang-Undang nomor 20 tahun 2011 jo. Undang-Undang nomor 31 tahun 1999 tentang Pemberantasan Tindak Pidana Korupsi, Pasal 55 Kitab Undang-Undang Hukum Pidana dan Pasal 65 Kitab Undang-Undang Hukum Pidana.
\end{abstract}

Kata Kunci: Perbarengan Perbuatan pidana, Penyertaan Perbuatan Pidana, Tindak Pidana Korupsi, Undang-Undang Pemberantasan Tindak Pidana Korupsi, Kitab Undang-Undang Hukum Pidana

In committing a criminal act known as the inclusion of criminal acts committed more than one person and 
Concursus criminal act which will be the determinant stelsel punishment to be used. Concursus criminal act is a criminal act committed more than one deed and is a criminal act that stands alone. In this regard, an Advocate STA gives money to the Supreme Court Judge twice in 2010 and 2013 in order to influence the decision to be decided by the Supreme Court Judge on the case being filed by the STA. STA is a perpetrator of corruption under Article 6 Paragraph (1) Sub-Paragraph a of Law No. 20 of 2011 jo. Law number 31 of 1999 on the Eradication of Corruption, Article 55 of the Criminal Code and Article 65 of the Criminal Code.

Keyword: Concursus Criminal Act. Inclusion of Criminal Acts. Corruption. Corruption Eradication Act. Book of the Criminal Justice Act.

\section{PENDAHULUAN}

Korupsi merupakan perilaku pejabat publik, baik politisi maupun pegawai negeri yang tidak wajar dan tidak legal memperkaya diri atau memperkaya mereka yang dekat dengannya dengan menyalahgunakan kekuasaan publik yang dipercaya kepada mereka.1 Tindak pidana korupsi sangat erat kaitannya dengan jabatan atau kekuasaan yang dimilikinya. Hal tersebut dikarenakan korupsi salah satunya dapat terjadi ketika mereka menghalalkan segala cara atau melakukan berbagai hal yang bertolak belakang terhadap tugas dan kewajibannya demi mendapatkan keuntungan pribadi. O.C.Kaligis berpendapat "Korupsi ada jika seseorang secara tidak sah meletakkan kepentingan pribadinya di atas kepentingan rakyat serta cita-cita yang menurut sumpah akan dilayaninya".2

Permasalahan terkait dengan kejahatan Korupsi, tidak hanya dirasakan oleh negara Indonesia, tetapi hampir seluruh negara didunia turut merasakan dampak dari adanya kejahatan korupsi. Penyebaran kehajahatan Korupsi yang begitu cepat membuat kejahatan korupsi tidak hanya dilakukan oleh kalangan tertentu dalam omasyarakat. Masalah korupsi bukan lagi sebagai masalah baru dalam persoalan hukum dan ekonomi bagi suatu negara karena masalah korupsi telah ada sejak ribuan tahun yang lalu, baik di negara maju maupun di negara berkembang termasuk juga di Indonesia. Bahkan perkembangan masalah korupsi di Indonesia saat ini sudah demikian parahnya dan menjadi masalah yang sangat luar biasa karena sudah menjangkit dan menyebar ke seluruh lapisan masyarakat.3

Tindak pidana korupsi di Indonesia telah memasuki tahap yang sangat membahayakan. Hal tersebut dapat dilihat dari tingkat kejahatan korupsi di Indonesia yang semakin meningkat.

1 Firman Wijaya, Peradilan Korupsi Teori dan Praktik, Maharini Press, Jakarta, 2008, hlm. 9

2 O.C.Kaligis, Pengawasan Terhadap Jaksa Selaku Penyidik Tindak Pidana Khusus dalam

Pemberantasan Korupsi, PT Alumni, Bandung, 2006, hlm. 72 2005, hlm. 1

3 Edina Yunara, Korupsi dan Pertanggungjawaban Pidana Korporasi, PT Citra Aditya Bakti, Bandung, 
Meningkatnya kejahatan korupsi di Indonesia, membuat kejahatan korupsi menjadi sesuatu hal yang biasa atau lazim dilakukan dalam ruang lingkup masyarakat. Kebiasaan itulah yang membuat korupsi semakin merajarela dan membudidaya ditengah masyarakat, terutama di kalangan para pegawai negeri sipil atau penyelanggara negara yang memiliki kewenangan atau kekuasaan tertentu. Evi Hartanti berpendapat meningkatnya tindak pidana korupsi yang tidak terkendali akan membawa bencana, tidak saja bagi kehidupan perekonomian nasional, juga pada kehidupan berbangsa dan bernegara. Hasil survey Transparency International Indonesia (TII) 2 menunjukan, Indonesia merupakan negara paling korup nomor 6 dari 133 negara. Peringkat itu disebabkan oleh korupsi dari level atas ke bawah yang begitu menjamur di Indonesia.Fakta lain mengenai penanganan kasus tindak pidana korupsi di Indonesia yaitu budaya hukum elit penguasa tidak menghargai kedaulatan hukum, tetapi lebih mementingkan status sosial si koruptor dengan melihat kekuasaan politik atau kekuatan ekonominya. Praktek penegakan hukum seperti ini bertentangan dengan kaidah prasyarat bernegara hukum.4

Salah satu bentuk kejahatan korupsi adalah tindak pidana korupsi suap. Suap (bribery) bermula dari asal kata briberie (Perancis) yang artinya adalah 'begging' (mengemis) atau 'vagrancy' (penggelandangan). Dalam bahasa Latin disebut briba, yang artinya 'a piece of bread given to beggar' (sepotong roti yang diberikan kepada pengemis). Dalam perkembangannya bribe bermakna 'sedekah' (alms), 'blackmail', atau 'extortion' (pemerasan) dalam kaitannya dengan 'gifts received or given in order to influence corruptly' (pemberian atau hadiah yang diterima atau diberikan dengan maksud untuk memengaruhi secara jahat atau korup). Dengan demikian seseorang yang terlibat dalam perbuatan suap menyuap sebenarnya harus malu apabila menghayati makna dari kata suap yang sangat tercela dan bahkan sangat merendahkan martabat kemanusiaan, terutama bagi si penerima suap. 5

Perbuatan tindak pidana korupsi yang sudah menjadi sebuah kebiasaan dalam lingkup masyarakat tentunya membuat kualitas setiap manusia dalam masyarakat menjadi menurun. Manusia yang dapat menjadi subyek tindak pidana korupsi di Indonesia terbagi menjadi 2 (dua) yaitu tindak pidana korupsi umum dan tindak pidana korupsi pegawai negeri dan atau penyelanggara negara. Tindak pidana korupsi umum ialah bentuk-bentuk tindak pidana korupsi yang ditujukan tidak terbatas kepada orang-orang yang berkualitas sebagai pegawai negeri, akan tetapi ditujukan pada setiap orang termasuk korporasi. Sedangkan tindak pidana korupsi pegawai negeri dan atau penyelenggara negara adalah tindak pidana korupsi yang hanya dapat dilakukan oleh orang yang berkualitas sebagai pegawai negeri atau penyelanggara negara. 6

\section{METODE PENELITIAN}

Tipe penulisan yang digunakan adalah penulisan hukum yuridis normatif, yaitu penulisan kepustakaan (law in books) berdasarkan bahan hukum primer yang berasal dari peraturan perundangundangan, dan bahan hukum sekunder yang berupa teori-teori dan literatur-literatur yang relevan terhadap permasalahan yang dibahas. Bahan-bahan hukum tersebut dikaitkan dengan permasalahan yang dibahas.

Di dalam penulisan ini, ada dua pendekatan masalah yang digunakan, yaitu Statute Approach merupakan pendekatan masalah yang dilakukan dengan menelaah serta membahas peraturan perundang-undangan yang berlaku yang berkaitan dengan isu hukum yang sedang dibahas, dan Conceptual Approach merupakan pendekatan masalah dengan merujuk pendapat-pendapat para sarjana yang terdapat dalam literatur-literatur yang relevan sebagai landasan pendukung.

4 Evi Hartanti, Tindak Pidana Korupsi, Sinar Grafika, Jakarta, 2007, hlm.2

5 Muladi, Hakekat Suap dan Korupsi, diakses dari

http://www.unisosdem.org/article_detail.php?aid=5118\&coid=3\&caid=22\&gid=3, pada tanggal 29 September 2017 pukul 13.00.

6 Adami Chazawi, Hukum Pidana Materiil dan Formil, Bayumedia Publishing, 2011, hlm. 23 


\section{HASIL DAN PEMBAHASAN}

Sebuah tindak pidana tentunya akan merujuk kepada dilarangnya suatu perbuatan pidana. Moeljatno berpendapat, "Perbuatan pidana adalah perbuatan yang dilarang oleh suatu aturan hukum, larangan mana disertai ancaman (sanksi) yang berupa pidana tertentu, bagi barangsiapa melanggar larangan tersebut".7 Dapat dipahami bahwa ketika seseorang melakukan perbuatan yang melanggar aturan hukum yang disertai dengan ancaman sanksi, maka perbuatan tersebut merupakan perbuatan pidana.

Secara yuridis Undang-Undang Pemberantasan Tindak Pidana Korupsi mengatur tindak pidana korupsi suap bagi yang memberi suap maupun bagi yang menerima suap. Salah satu pasal yang mengatur tentang pemberian suap yaitu Pasal 6 Ayat 1 huruf a Undang-Undang Pemberantasan Tindak Pidana Korupsi yang memuat dipidana dengan pidana penjara paling singkat 3 (tiga) tahun dan paling lama 15 (lima belas) tahun dan pidana denda paling sedikit Rp. 150.000.000,00 (seratus lima puluh juta rupiah) dan paling banyak Rp. 750.000.000,00 (tujuh ratus lima puluh juta rupiah): setiap orang yang memberi atau menjanjikan sesuatu kepada hakim dengan maksud untuk mempengaruhi putusan perkara yang diserahkan kepadanya untuk diadili.

Adapun unsur-unsur yang terkadang dalam Pasal 6 Ayat 1 huruf a Undang-Undang Pemberantasan Tindak Pidana Korupsi, dijelaskan sebagai berikut:

Unsur yang pertama adalah unsur setiap orang. Unsur setiap orang dalam Pasal 6 ayat (1) huruf a UU PTPK disini dapat dimaknai tanpa terkecuali. Setiap orang yaitu siapapun orangnya dapat memenuhi unsur "setiap orang" yang ada dalam pasal ini tanpa terkecuali. Dalam pasal ini tidak terdapat suatu bentuk kekhususan terhadap orang tertentu saja yang dapat memenuhi pasal ini, melainkan semua orang tanpa terkecuali dapat dijerat dengan menggunakan pasal ini, termasuk seseorang yang berprofesi sebagai Advokat. Pasal 1 Angka 3 UU PTPK menyatakan bahwa pengertian orang dalam tindak pidana korupsi yaitu "orang perseorangan atau termasuk korporasi" STA yang merupakan seorang (individu) kuasa hukum atau Advokat telah memenuhi unsur "setiap orang" dalam Pasal 1 Angka 3 UU PTPK sebagai "orang perseorangan”

Unsur yang kedua adalah memberi atau menjanjikan sesuatu. Terhadap unsur yang kedua ini, terdapat perbedaan antara memberi dan menjanjikan sebagaimana yang telah saya paparkan sebelumnya bahwa dalam hal memberi sesuatu artinya sesuatu yang dimaksud tersebut telah berpindah tangan atau telah beralih dari orang yang memberi kepada orang yang diberi.8 Beralihnya kekuasaan atas sesuatu tersebut artinya si penerima bebas untuk menikmati dan juga memiliki sesuatu tersebut yang diberikan oleh si pemberi. Pengertian memberikan sesuatu disini haruslah sebuah perbuatan yang sudah selesai atau sempurna. Namun, didalam UU PTPK juga mengenal adanya suatu bentuk pemberian yang tidak selesai atau tidak sempurna. Terhadap bentuk pemidanaan dari pemberian sesuatu yang belum selesai secara sempurna tersebut akan dipidana sama dengan perbuatan yang selesai sebagaimana yang telah tercantum dalam Pasal 15 UU PTPK yang menentukan bahwa, "Setiap orang yang melakukan percobaan, pembantuan, atau pemufakatan jahat untuk melakukan tindak pidana korupsi, dipidana dengan pidana yang sama sebagaimana dimaksud dalam Pasal 2, Pasal 3, Pasal 5 sampai dengan Pasal 14". Sehingga perbuatan memberi sesuatu yang belum selesai bentuk pidananya disamakan dengan perbuatan memberi sesuatu yang selesai secara sempurna.

Dikaitkan dengan uraian kasus di atas, maka STA telah memenuhi unsur "memberi sesuatu", bukan "menjanjikan sesuatu". Unsur memberi sesuatu yang dipenuhi oleh STA berasal dari perbuatan

7 Moeljatno, Azas-Azas Hukum Pidana, Gadjah Mada University Press, Yogyakarta, 1980, (selanjutnya disingkat Moeljatno I), hlm. 37

8 Adami Chazawi, op.cit, hlm. 169 
belum selesai atau percobaan korupsi suap yang telah dianggap sebagai perbuatan selesai dari sisi bentuk pidananya berdasarkan Pasal 15 UU PTPK. Hal tersebut terbukti ketika STA telah membawa uang sebesar Rp.1.000.000.000,00 (satu milyar rupiah) untuk MA di Mahkamah Konstitusi namun MA belum dapat menerima uang tersebut karena masih proses sidang Jatim dan MA berkata bahwa akan melakukan kontak lagi dengan STA. Akan tetapi, MA telah mengatahui bahwa STA ingin bertemu dengan dirinya untuk memberikan uang atas putusannya yang mengabulkan permohonan keberatan berita acara kabupaten Lebak yang diajukan oleh STA. Disini terbukti bahwa STA memberikan sesuatu ketika telah membawa uang sebesar Rp. 1.000.000.000,00 (satu milyar rupiah), akan tetapi terkendala karena MA masih berada dalam sidang sehingga uang tersebut dibawa pulang ke rumah orang tua STA. Pada saat STA telah berada di MK dengan membawa uang tersebut dengan tujuan untuk memberikan uang tersebut kepada MA, maka hal tersebut sudah merupakan bentuk percobaan korupsi suap yang didalam tindak pidana korupsi dianggap sebagai bentuk perbuatan yang selesai dari sisi bentuk pemidanaannya.

Dakwaan yang kedua memenuhi unsur memberi sesuatu ketika STA memberikan uang tersebut dengan cara mengirim uang sebesar Rp. 250.000.000,00 (dua ratus lima puluh juta rupiah) melalui Bank BNI Jakarta Pusat kepada rekening atas nama MA dan kembali mengirimkan uang sebesar Rp. 250.000.000,00 (dua ratus lima puluh juta rupiah) melalui Bank Mandiri Cabang Bandar Lampung Teuku Umar kepada RR selaku istri MA dengan atas nama rekening tujuan CV. RATU SAMAGAT. Sehingga total yang dikirimkan atau diberikan oleh STA kepada MA adalah sebesar Rp. $500.000 .000,00$ (lima ratus juta rupiah) sesuai dengan besaran nilai yang diminta oleh MA agar permohonan dari STA dapat dikabulkan dipersidangan.

Unsur yang ketiga adalah Hakim. Sebagaimana yang telah saya jabarkan sebelumnya bahwa didalam UU PTPK maupun KUHP tidak dijelaskan tentang siapa itu hakim. Tetapi dalam Pasal 92 ayat (2) KUHP memberikan keterangan tentang perluasan cakupan dari pengertian hakim yang dapat disimpulkan sebagai berikut:

1. Pejabat/pegawai negeri adalah juga termasuk hakim

2. Hakim adalah termasuk juga hakim wasit

3. Hakim adalah termasuk juga orang yang menjalankan peradilan administratif

4. Hakim adalah termasuk juga ketua-ketua dan anggota peradilan agama.9

Pengertian Hakim menurut Pasal 1 angka 8 KUHAP yaitu "Hakim adalah pejabat peradilan negara yang diberi wewenang oleh undang-undang untuk mengadili". Sehingga telah terbukti bahwa Hakim adalah seorang pejabat sesuai dengan perluasan cakupan dari pengertian hakim dalam Pasal 92 ayat (2) KUHP.

Dalam dakwaan yang pertama, MA terpilih sebagai Ketua Panel Hakim bersama dengan MF dan AU sebagai Hakim anggota berdasarkan Ketetapan Ketua Mahkamah Konstitusi Republik Indonesia Nomor: 747/TAP.MK/2013 tanggal 12 September 2013. Dalam dakwaan yang kedua, MA ditunjuk sebagai Ketua Panel Hakim bersama dengan MA dan HZ sebagai Hakim anggota berdasarkan ketetapan Ketua Mahkamah Konstitusi Republik Indonesia sebagai berikut:

- Nomor: 325/TAP.MK/2010 tentang Pembentukan Panel Hakim untuk Memeriksa Permohonan Nomor Registrasi: 76/PHPU.D-VIII/2010

- Nomor: 327/TAP.MK/2010 tentang Pembentukan Panel Hakim untuk Memeriksa Permohonan Nomor Registrasi: 78/PHPU.D-VIII/2010

- Nomor: 329/TAP.MK/2010 tentang Pembentukan Panel Hakim untuk Memeriksa Permohonan Nomor Registrasi: 80/PHPU.D-VII/2010 
MA merupakan seorang Hakim yang bertugas di Mahkamah Konstitusi, dimana Hakim Mahkamah konstitusi pada Mahkamah Konstitusi juga merupakan bagian dari pengertian seorang Hakim. Hal tersebut dinyatakan oleh R. Wiyono yaitu :

Pejabat peradilan negara yang diberi wewenang oleh undang-undang untuk mengadili. Dengan merujuk pada ketentuan yang terdapat dalam Pasal 2 Undang-Undang RI Nomor 4 Tahun 2004 tentang Kekuasaan Kehakiman dan Undang-Undang RI Nomot 24 Tahun 2003 tentang Mahkamah Konstitusi, yang termasuk Hakim adalah :

1. Hakim pada semua lingkungan peradilan, yaitu:

- Peradilan Umum

- Peradilan Agama

- Peradilan Militer

- Peradilan Tata Usaha Negara

2. Hakim Agung pada Mahkamah Agung RI

3. Hakim Konstitusi pada Mahkamah Konstitusi.10

Unsur yang keempat adalah dengan maksud untuk mempengaruhi putusan perkara yang diserahkan kepadanya untuk diadili. Unsur ini tentunya berangkat dari unsur memberi atau menjanjikan sesuatu yang akhirnya dari unsur tersebut memiliki akibat terhadap terpengaruhinya sebuah putusan perkara yang diserahkan kepada Hakim untuk diadili sehingga unsur ini disebut sebagai unsur subyektif. Dalam unsur ini tidak perlu dibuktikan apakah Hakim benar-benar telah terpengaruh oleh sesuatu yang telah diberikan karena pasal ini merupakan pasal yang bersifat delik formil sehingga yang ditekankan dalam pasal ini adalah perbuatannya yaitu memberi atau menjanjikan sesuatu.

Dalam dakwaan yang pertama, unsur dengan maksud untuk mempengaruhi putusan perkara yang diserahkan kepadanya untuk diadili terbukti ketika niat awal dari RA yang menyarankan untuk dilakukan penyelesaian perkara dengan bantuan MA, kemudian STA menghubungi MA dan menyampaikan keinginan RA, MA pun menyampaikan bahwa jika ingin memenangkan perkara Lebak maka harus menyiapkan dana sebesar Rp. 3.000.000.000,00 (tiga milyar rupiah). Namun dikarenakan AH dan $\mathrm{K}$ tidak mempunyai uang, sehingga AH dan K meminta bantuan RA melalui TC karena RA telah melimpahkan urusan perkara Lebak kepada TC. Melalui persetujuan RA, TC pun hanya bersedia memberikan uang sebesar Rp. 1.000.000.000,00 (satu milyar rupiah). Pada saat STA menyampaikan bahwa hanya tersedia uang Rp. 1.000.000.000,00 (satu milyar rupiah), STA juga mengatakan melalui SMS kepada MA yang berisi "tolong bantu lebak dululah pak". Melalui bukti STA saat menghubungi MA untuk menyampaikan saran dari RA untuk meminta bantuan kepada MA, dan saat STA berusaha membujuk MA untuk menerima uang sebesar Rp. 1.000.000.000,00 (satu milyar rupiah) dan mengatakan tolong bantu lebak dulu, hal tersebut sudah menjadi bukti yang kuat bahwa perbuatan unsut memberi atau menjanjiakn sesuatu dari pasal ini berdampak atau mengakibatkan terhadap terpengaruhinya sebuah putusan. Namun tidak perlu dibuktikan apakah dengan sesuatu yang diberikan tersebut hakim benar-benar terpengaruh atau tidak, karena unsur ini merupakan unsur subyektif.

Dalam dakwaan yang kedua, unsur dengan maksud untuk mempengaruhi putusan perkara yang diserahkan kepadanya untuk diadili juga sudah terpenuhi. Hal tersebut terbukti ketika MA menghubungi STA melalui telepon dengan menyampaikan bahwa terkait permohonan keberatan atas rekapitulasi hasil perhitungan perolehan suara tingkat Kabupaten Lampung Selatan tahun 2010 agar disediakan uang sebesar Rp. 500.000.000,00 (lima ratus juta rupiah). Dari apa yang disampaikan oleh MA, terbukti bahwa jika STA memberikan uang sebesar Rp. 500.000.000,00 (lima ratus juta rupiah), maka MA akan berada di pihak STA atau memenangkan perkara yang ditangani STA dengan menyatakan bahwa permohonan para pemohon tidak dapat diterima.

10 R. Wiyono, Pembahasan Undang-Undang Pemberantasan Tindak Pidana Korupsi, Sinar Grafika, Jakarta, 2005, hlm. 53-54 
Bahwa dalam perkara tindak pidana korupsi yang dilakukan STA, juga melibatkan lebih dari 1 (satu) orang pelaku tindak pidana yaitu STA, AH, K, TC, dan RA yang terdapat dalam dakwaan pertama dan melibatkan STA, RM dan ES yang terdapat dalam dakwaan kedua. Tindak pidana yang dilakukan lebih dari 1 (satu) orang diatur dalam Pasal 55 Ayat (1) ke-1 KUJHP yang menyatakan bahwa, "Dihukum sebagai orang yang melakukan peristiwa pidana: orang yang melakukan, yang menyuruh melakukan, atau turut serta melakukan perbuatan itu". Berdasarkan dari paparan teori sebelumnya, bahwa salah satu klasifikasi terpenuhinya unsur sebagai pleger atau orang yang melakukan dalam pasal ini adalah jika terdakwa memenuhi semua unsur pasal yang dijerat. Oleh sebab itu, STA telah memenuhi pula Pasal 55 Ayat (1) ke-1 KUHP sebagai orang yang melakukan atau Pleger karena telah terbukti memenuhi semua unsur dalam Pasal 6 ayat (1) huruf a.

Tindak pidana korupsi merupakan sebuah tindak pidana yang juga dapat melibatkan lebih dari satu pihak sebagaimana dengan teori yang telah saya jabarkan sebelumnya. Begitu pula dalam kasus STA yang tidak hanya terdapat peran dari STA dalam melakukan perbuatan pidana korupsi suap, tetapi terdapat peran dari beberapa orang yang terkait. Perbuatan pidana yang dilakukan lebih dari 1 (satu) orang disini, telah ditentukan dalam KUHP Pasal 55 tentang turut serta. Pasal 55 ayat (1) ke-1 KUHP menentukan, "dipidana sebagai pelaku tindak pidana: mereka yang melakukan, yang menyuruh melakukan, dan yang turut serta melakukan perbuatan". Berdasarkan dari ketentuan Pasal 55 KUHP tersebut, maka peran dari STA adalah sebagai mereka yang melakukan atau pleger. Hal tersebut dikarenakan salah satu syarat terpenuhinya posisi sebagai pleger adalah jika ia memenuhi semua unsur dari pasal yang jerat kepadanya. Sedangkan dalam kasus STA ini, STA telah memenuhi seluruh unsur dari Pasal 6 ayat (1) huruf a dari dakwaan pertama maupun dakwaan kedua.

Dakwaan yang didakwa oleh penuntut umum merupakan dakwaan berbentuk kumulatif, di mana STA melakukan tindak pidana korupsi suap kepada MA sebanyak 2 (dua) kali dengan tujuan yang sama yaitu untuk mempengaruhi putusan yang akan diadili oleh MA namun terdapat 2 (dua) kepentingan yang berbeda. Sehingga STA juga telah melakukan perbarengan dari perbuatan tindak pidana. Perbarengan tindak pidana korupsi suap yang dilakukan STA tergolong dalam concursus realis berdasarkan Pasal 65 KUHP yang menyatakan:

(1) Dalam hal perbarengan beberapa perbuatan yang harus dipandang sebagai perbuatan yang berdiri sendiri sehingga merupakan beberapa kejahatan, yang diancam dengan pidana pokok yang sejenis, maka dijatuhkan hanya satu pidana.

(2) Maksimum pidana yang dijatuhkan ialah jumlah maksimum pidana yang diancam terhadap perbuatan itu, tetapi boleh lebih dari maksimum pidana yang trerberat ditambah sepertiga.

Perbarengan perbuatan tindak pidana yang dilakukan oleh STA dilakukan sebanyak 2 (dua) kali pada tahun 5 Agustus 2010 dan 1 Oktober 2013. Kedua perbuatan tindak pidana tersebut diadili secara sekaligus karena tidak ada putusan Hakim untuk perbuatan tindak pidana korupsi suap terdahulu yaitu tahun 2010 yang dilakukan oleh STA. Kedua perbuatan STA tersebut juga merupakan perbuatan tindak pidana yang berdiri sendiri karena memiliki 2 (dua) tujuan yang berbeda, bukan 1 (satu) tujuan dimana dalam dakwaan yang pertama tujuan STA memberikan uang kepada MA agar mengabulkan permohonan keberatan KPU berita acara kabupaten Lebak yang diajukan oleh AH dan K sedangkan dakwaan yang kedua tujuannya agar MA mengabulkan permohonan keberatan berita acara KPU Lampung yang diajukan oleh RM dan ES

STA yang melakukan tindak pidana korupsi suap dijerat dengan pasal yang sama yaitu Pasal 6 Ayat (1) huruf a sehingga memiliki ancaman pidana pokok yang sejenis. Pasal 65 KUHP menyatakan:

(1) Dalam hal perbarengan beberapa perbuatan yang harus dipandang sebagai perbuatan yang berdiri sendiri sehingga merupakan beberapa kejahatan, yang diancam dengan pidana pokok yang sejenis, maka dijatuhkan hanya satu pidana. 
(2) Maksimum pidana yang dijatuhkan ialah jumlah maksimum pidana yang diancam terhadap perbuatan itu, tetapi boleh lebih dari maksimum pidana yang terberat ditambah sepertiga.

Pasal 65 Ayat (2) KUHP menyatakan bahwa penjatuhan pidana atas perbuatan perbarengan tindak pidana Pasal 65 Ayat (1) KUHP terdapat penambahan sepertiga dari maksimum pidana yang dijatuhkan. STA dijerat dengan Pasal 6 Ayat (1) huruf a yang memiliki maksimum pidana selama 15 (lima belas) tahun penjara. Sehingga, penjatuhan pidana kepada STA adalah 15 (lima belas) tahun penjara ditambah sepertiga menjadi 20 (dua puluh) tahun penjara.

Seseorang yang telah melakukan suatu perbuatan pidana akan dikaitkan dengan suatu pertanggungjawaban pidana. Salah satu doktrin hukum pidana menyatakan actus non facit reum nisi men sit rea yang artinya adalah tidak dipidana jika tidak ada kesalahan. Sehingga seseorang hanya dapat dikenakan sebuah pertanggungjawaban pidana apabila terdapat sebuah unsur kesalahan didalam perbuatan tindak pidana yang dilakukannya. Bila tidak terdapat unsur kesalahan didalam perbuatan pidananya, maka tidak dapat dikenakan pertanggungjawaban pidana. Berikut adalah beberapa unsur kesalahan yang harus dipenuhi oleh seseorang agar dapat dikenakan pertanggungjawaban pidana:

Pertama, terkait dengan kemampuan dari si pelaku dalam arti jiwa si pelaku dalam keadaan sehat dan normal. Seseorang hanya dapat dimintakan pertanggungjawaban pidana jika keadaan jiwanya dalam keadaan sehat tanpa gangguan apapun. Hal tersebut tertuang dalam Pasal 44 KUHP yang menentukan, "Barangsiapa melakukan perbuatan yang tidak dapat dipertanggungkan kepadanya karena jiwanya cacat dalam pertumbuhan atau terganggu karena penyakit, tidak dipidana". Berdasarkan uraian kronologis kasus di atas, STA melakukan korupsi suap sebanyak 2 (dua) kali dalam kondisi jiwa yang baik tanpa ada gangguan apapun. Seperti yang telah saya uraikan sebelumnya bahwa Roeslan Saleh berpendapat, "Bilamana akalnya sehat dan normal, artinya bilamanya orang mampu membeda-bedakan antara perbuatan yang diperbolehkan atau tidak diperbolehkan".11 Begitu pula dalam kasus ini, di mana STA yang berprofesi sebagai advokat mengetahui bahwa perbuatannya dalam memberikan suap kepada MA merupakan sebuah tindak pidana yang dilarang oleh UU PTPK. Selain itu, terbukti bahwa STA telah menutupi perbuatannya karena sadar bahwa perbuatannya tersebut merupakan bentuk tindak pidana pada saat STA melakukan pengiriman uang sebanyak 2 (dua) kali yang ditujukan kepada MA melalui formulir kiriman bank BNI dengan mencantumkan tujuan pengiriman uang seolah-olah terdapat hubungan usaha antara STA dengan MA dengan menuliskan "pembayaran kelapa sawit) dan pengiriman uang yang kedua kepada RR selaku istri dari MA melalui formulir kiriman bank Mandiri dengan menuliskan berita acara "pembayaran tagihan", seolah-olah terdapat hubungan usaha antara STA dengan RR yang merupakan istri MA. Selain itu, perbuatan STA untuk membujuk MA menerima uang sebesar Rp. 1.000.000.000,00 (satu milyar rupiah) dilakukannya secara sadar bahwa tujuan dari yang ia lakukan adalah agar MA mengabulkan permohonan kliennya yaitu EM dan ES.

Kedua, terkait dengan pemenuhan salah satu unsur antara kesengajaan (dolus) atau kealpaan (culpa). Sesuai dengan kronologis kasus yang telah diuraikan, bahwa kasus STA telah memenuhi unsur kesengajaan atau dolus. Sianturi berpendapat yang dimaksud dengan kesengajaan yaitu, "suatu kehendak (keinginan) untuk melaksanakan suatu tindakan yang didorong oleh pemenuhan nafsu dengan perkataan lain, kesengajaan ditujukan terhadap suatu tindakan".12 Bentuk kesengajaan yang dilakukan oleh STA adalah bentuk kesengajaan sebagai maksud, hal tersebut dibuktikan dengan tindakannya yang telah menghubungi MA untuk memberikan suap sebesar Rp. 1.000.000.000,00 (satu milyar rupiah) untuk memenangkan perkara konstitusi nomor: 111/PHPU.D-XI/2013 tanggal 11 September 2013 yang diajukan oleh AH dan K yang ditangani oleh STA. Selain itu, terbukti unsur

11 Roeslan Saleh, Perbuatan Pidana dan Pertanggungjawaban Pidana: Dua Pengertian Dasar dalam Hukum Pidana, Aksara Baru, Jakarta, 1983, hlm. 81

12 Sianturi, Asas-Asas Hukum Pidana di Indonesia dan Penerapannya, alumni, jakarta, 1986, hlm. 167 
kesengajaan yang dilakukan oleh STA pada saat STA memberikan suap sebesar Rp. 500.000.000,00 (lima ratus juta rupiah) yang kirimkan melalui aplikasi setoran tunai Bank Mandiri sebanyak Rp. 250.000.000,00 (dua ratus lima puluh juta rupiah) kepada rekening RR yaitu istri dari MA dan pengiriman kedua dilakukan melalui formulir pengiriman bank BNI sebanyak Rp. 250.000.000,00 (dua ratus lima puluh juta rupiah) yang ditujukan kepada rekening MA.

Ketiga, terkait dengan tidak adanya alasan pelaku yang dapat menghapuskan kesalahan yaitu alasan pemaaf. Moeljatno menyatakan bahwa alasan pemaaf yaitu "Alasan yang menghapuskan kesalahan terdakwa. Perbuatan yang dilakukan oleh terdakwa tetap bersifat melawan hukum jadi tetap merupakan perbuatan pidana, tetapi dia tidak dipidana, karena tidak ada kesalahan".13 Alasan pemaaf tidak berlaku bagi seseorang yang tidak normal atau memiliki gangguan jiwa sesuai dengan Pasal 44 KUHP. Pada saat STA melakukan suap kepada MA untuk mempengaruhi putusan MA dalam memutus perkara yang ditanganinya, STA berada didalam keadaan sadar dengan kondisi jiwa yang normal. Sehingga alasan pemaaf tidak berlaku bagi STA.

\section{KESIMPULAN}

Berdasarkan uraian dan pembahasan sebagaimana yang telah dipaparkan pada bab-bab sebelumnya maka dapat disimpulkan bahwa STA telah melakukan perbarengan dari perbuatan korupsi suap secara bersama-sama yang dapat dikenakan pertanggungjawaban pidana sebagai berikut:

1. Putusan yang dijatuhkan oleh Mahkamah Konstitusi untuk STA yaitu Pasal 12 huruf c UU PTPK jo. Pasal 55 KUHP tidak tepat, seharusnya STA dikenakan pertanggungjawaban pidana berdasarkan Pasal 6 Ayat (1) huruf a UU PTPK jo. Pasal 55 KUHP jo. Pasal 65 KUHP.

2. STA dikenakan pertanggungjawaban pidana karena terdapat kesalahan. Unsur-unsur kesalahan tersebut:

a. STA telah melakukan perbuatan melawan hukum dengan cara melakukan perbarengan dari perbuatan korupsi suap secara bersama-sama dengan cara memberikan uang kepada Hakim MA untuk mempengaruhi putusan yang sedang yang ditangani oleh STA.

b. STA adalah orang dewasa dengan keadaan sehat dan normal sehingga mampu untuk bertanggungjawab.

c. Memenuhi bentuk kesalahan yaitu kesengajaan pada saat STA secara sengaja memberikan uang kepada MA dengan maksud mempengaruhi putusan perkara yang akan diadil oleh MA.

d. Terhadap STA tidak terdapat alasan pemaaf.

\section{REFERENSI}

Wijaya, Firman Peradilan Korupsi Teori dan Praktik, Maharini Press, Jakarta, 2008.

Yunara,Edina. Korupsi dan Pertanggungjawaban Pidana Korporasi, PT Citra Aditya Bakti, Bandung, 2005.

Kaligis, O.C. Pengawasan Terhadap Jaksa Selaku Penyidik Tindak Pidana Khusus dalam Pemberantasan Korupsi, Alumni, Bandung, 2006.

Hartanti, Evi. Tindak Pidana Korupsi, Sinar Grafika, Jakarta, 2007.

Chazawi, Adami. Hukum Pidana Materiil dan Formil, Bayumedia Publishing, 2011.

Wiyono, R. Pembahasan Undang-Undang Pemberantasan Tindak Pidana Korupsi, Sinar Grafika, Jakarta, 2005.

Moeljatno, Azas-Azas Hukum Pidana, Gadjah Mada University Press, Yogyakarta, 1980. , Azas-Azas Hukum Pidana, Bina Aksara, 1983

13 Moeljatno II, op.cit, 137 
Saleh, Roeslan. Perbuatan Pidana dan Pertanggungjawaban Pidana: Dua Pengertian Dasar dalam Hukum Pidana, Aksara Baru, Jakarta, 1983.

Sianturi, Asas-Asas Hukum Pidana di Indonesia dan Penerapannya, alumni, jakarta, 1986.

Muladi,

$$
\text { Hakekat }
$$

Suap

dan

Korupsi,

diakses

dari http://www.unisosdem.org/article_detail.php?aid=5118\&coid=3\&caid=22\&gid=3, tanggal 29 September 2017 pukul 13.00 . 